Piotr Wajszczyk

Łódź University of Technology

e-mail: piotr.wajszczyk@p.lodz.pl

\title{
The Role of Discretion in Professional Practice*
}

\begin{abstract}
Various scholars of ethics and economics conduct research on the best modes of decision making which guarantee good outcome and moral behaviour of the individuals involved. Either of the modes considered, rules with regulations or discretion and judgment, find applicability in diversified professional circumstances. The paper investigates how discretion can be used in professional activity by using the Aristotelic-Thomistic framework. Results indicate that such a framework can be used by engineers in their working environments and by other working professionals with the main proposition that only in discretionary decision making is the person able to take full responsibility for the outcomes and to premeditate their moral worth in conscience before resolving to commit the act itself.
\end{abstract}

Keywords: personalistic professionalism in engineering ethics, discretion, human decision making, conscience, truth

JEL Classification: A13, D81

\section{Introdution}

So far few attempts have been made to provide an in-depth insight into the process of committing a moral act by a professional human being, with the help of either rules or discretion. Even fewer attempts were made to combine these internal and external processes into the seamless operation of a human being. This paper shows how it is applicable to use discretion in professional ethical judgment.

\footnotetext{
* The article provides a continuation of reasoning presented by the author in the paper published in "Annales. Etyka w Życiu Gospodarczym/Annales. Ethics in Economic Life" a year ago (P. Wajszczyk, Discretion in Professional Practice and in Engineering Ethics, "Annales. Etyka w Życiu Gospodarczym" 2015, Vol. 18, No. 4, December 2015, pp. 129-136)
} 
It shall be argued that the discretion of an acting person can only result in moral choices when acts are done with the whole involvement of the acting person's inner faculties rather than impersonally. Only then are appropriate virtues built and professional skills combined with them.

\section{Rules $v s$. discretion in the economic and professional literature}

Davis ${ }^{1}$ was one of the few authors in the professional engineering literature who recognized the importance of professional judgment for science and engineering practice. To be a minimally competent engineer, ' (...) one must be able to identify fruitful problems, investigate them in the appropriate way, and draw useful conclusions. ${ }^{2}$ Since there is no single reliable algorithm for doing this in either science or engineering, central importance is placed on judgment and personal discretion for doing it rightly and reliably. It is especially important for ethical professional behaviour.

There are two opposing views on what to rely on during professional moral conduct. One group of views recommends the reliance on rules, which are more applicable in certain circumstances, while the other recommends personal discretion. A range of studies in the economic and professional literature is devoted to the investigation of the relationship between professional discretion and the narrow, specific outcomes of vocational practice.

Rules are best to be depended on in cases of high systemic risk, whenever an individual is incapable of predicting the probability of a natural disaster and coping with it. ${ }^{3}$ Obligatory private insurance options with hazard rate dependent insurance costs, partly subsidized by the state, should be the more efficient solution than there be sole dependence on the free market discretionary behaviour of land and property owners.

Rules can be mixed with discretionary actions in the form of exceptions to an established rule, if there is local information shared by the action taker and a second party who is able to verify for the larger group that an exception is warranted. The second party can then either excuse ex ante the action taker for the discretionary act or forgive a rule-breaking actor ex post. ${ }^{4}$

In the context of the producer-customer interface which operates using mass customization technologies, an important challenge there was the design of appropriate work roles and the management of task discretion in a product-service environment. The control of such task discretion ${ }^{5}$ was achieved by limiting customer

\footnotetext{
${ }^{1}$ M. Davis, A Plea for Judgment, "Science and Engineering Ethics" 2012, Vol. 18, p. 789.

${ }^{2}$ Ibidem, p. 790.

${ }^{3}$ H. Kunreuther, M. Pauly, Rules Rather Than Discretion: Lessons from Hurricane Katrina, "Journal of Risk and Uncertainty" 2006, Vol. 33, p. 103.

${ }^{4}$ T.R. Bowen, D.M. Kreps, A. Skrzypacz, Rules with Discretion and Local Information, "The Quarterly Journal of Economics” 2013, pp. 1273-1320.

${ }^{5}$ Discretion was defined there as: '(...) the freedom or authority to make judgements and to act as one sees fit, which is understood as the role holder's ability to make procedural decisions (the independence
} 
interaction to predefined encounters. This interaction prompted some organizations to separate the front-line from back-office work, with greater degree of discretion at the front-line emphasizing planning, selection and control of staff, customers and their codified interactions - all to achieve the target of a positive experience. This development indicates that the discretion in services offered can be manageable.

Managerial discretion is subject to research investigation in many separate pieces of research. It is ' $(. .$.$) the strategic freedom to act, or the latitude of action$ that managers have when they formulate strategic activities, including implementation of organizational structure, determination of corporate development strategy and execution of technology transformations. ${ }^{6}$ It has been found that when managers are given greater autonomy to organize management and service practices, their discretional abilities can actively enhance the discretion-performance relationship through task autonomy, contractual control and management compensation. ${ }^{7}$

Studies carried out among high-level management show how different managerial environments influence investors' and boards' reactions to third-party endorsements of managerial (CEO) quality differentiated according to (i.a.) the levels of managerial discretion (high vs. low). ${ }^{8}$

There are also analyses into how contractual incentives influence managerial discretion of asset write-downs in the context of the imposition of stricter verification standards (Generally Accepted Accounting Principles) vs. discretionary conservatism in accounting. ${ }^{9}$

Melé presented some shortcomings to approaches of ethical education in accounting which pertain to rules and principles, and values and virtues, which are treated in a fragmentary manner. He posited that the primary goal for ethical education in accounting 'should be to impact on the ethical behaviour of those receiving this education and not only to provide a set of theories and tools to solve ethical dilemmas. ${ }^{\prime 10}$ This should be done with character and virtues, which are a matter of personal moral development rather than exclusively knowledge.

Arnaud and Wasieleski trace how managerial discretion helps in development and maintenance of socially responsible outcomes at the individual level of the Corporate Social Performance model, assessing a firm's social responsibility. ${ }^{11}$

\footnotetext{
from others when making those decisions).' J. Angelis, G. Parry, M. Macintyre, Discretion and Complexity in Customer Focused Environments, "European Management Journal” 2012, Vol. 30, p. 468.

${ }^{6}$ Y. Yan, Ch.Ch. Yan, S. Mak, An Exploration of Managerial Discretion and Its Impact on Firm Performance: Task Autonomy, Contractual Control, and Compensation, "International Business Review" 2010, Vol. 19, p. 521.

${ }^{7}$ Ibidem, p. 528.

${ }^{8}$ T.L. Waldron, S.D. Graffin, J.F. Porac, J.B. Wade, Third-party Endorsements of CEO Quality, Managerial Discretion, and Stakeholder Reactions, "Journal of Business Research” 2013, Vol. 66, pp. 2592-2599.

${ }^{9}$ S. Roychowdhury, X. Martin, Understanding Discretion in Conservatism: An Alternative Viewpoint, "Journal of Accounting and Economics" 2013, Vol. 56, pp. 134-146.

${ }^{10}$ D. Melé, Ethical Education in Accounting: Integrating Rules, Values and Virtues, "Journal of Business Ethics” 2005, Vol. 57, p. 106.

${ }^{11}$ S. Arnaud, D.M. Wasieleski, Corporate Humanistic Responsibility: Social Performance through Managerial Discretion of the HRM, "Journal of Business Ethics" 2014, Vol. 120, pp. 313-334.
} 
Sahaym et al. investigate how capacity to offer innovative products, uncertainty, and managerial discretion has an impact on export driven internationalization. ${ }^{12}$

Naveh finds that unrestricted discretion in $R \& D$ projects offers a more positive relationship between formality and performance achievement in $R \& D$ projects than in projects with restricted members' discretion. ${ }^{13}$

Aragón-Correa et al. consider possible links between executive discretion and corporate environmental commitment. Their survey results from 105 firms show that a firm's environmental commitment is correlated with the responsibility of specific executives for environmental matters. This environmental commitment was found to be linked with those executives who had high levels of managerial discretion. ${ }^{14}$

Discretion is also considered to be a time-dependent phenomenon. Hutzschenreuter and Kleindienst develop an in-depth analysis of managerial discretion and its operation in strategic issue array. They develop a conceptual model by considering managerial discretion as a continuum of options with two constraints: those of which the manager is aware (MA) and those contained in the zone of acceptance

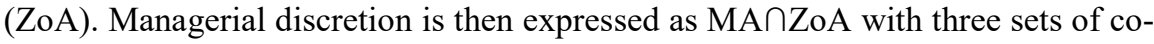
variates: personal characteristics, relational characteristics and situational characteristics. ${ }^{15}$

In the field of judiciary discretion, Einat analysed the link between sentencing rationales, judiciary discretion, and fining policy, especially the confidence in the ability of the criminal fine to successfully achieve different penal objectives, while in a comparative study Cooter and Ginsburg investigated the influence of factors on the relative amount of judicial discretion across different legal systems. ${ }^{16}$

There is a certain characteristic visible in the above literature: the authors, by uncovering relationships among the investigated concepts, create knowledge rules to be taken into account by the researchers and decision makers whenever they encounter the problems addressed by the authors. Little space and researchers' attention however, has been devoted to the subjects who find themselves in situations requiring the use of discretion. The literature sources quoted above seem to ignore the inner structure and dynamism of the acting persons behind the acts described.

\footnotetext{
${ }^{12}$ A. Sahaym, L.J. Treviño, H.K. Steensma, The influence of managerial discretion, innovation and uncertainty on export intensity: A real options perspective, "International Business Review" 2012, Vol. 21, pp. 1131-1147.

${ }^{13}$ E. Naveh, Formality and discretion in successful R\&D projects, "Journal of Operations Management" 2007, Vol. 25, pp. 110-125.

${ }^{14}$ J.A. Aragón-Correa, F. Matías-Reche, M.E. Senise-Barrio, Managerial discretion and corporate commitment to the natural environment, "Journal of Business Research" 2004, Vol. 57, pp. 964-975.

${ }^{15}$ T. Hutzschenreuter, I. Kleindienst, (How) Does discretion change over time? A contribution toward a dynamic view of managerial discretion, "Scandinavian Journal of Management" 2013, Vol. 29, pp. 264-281.

${ }_{16}$ T. Einat, Sentencing rationales, judicial discretion, and the practice of criminal fines in Israel, "Journal of Criminal Justice" 2008, Vol. 36, pp. 444-452, doi: 10.1016/j.jcrimjus.2008.07.007; R.D. Cooter, T. Ginsburg, Comparative Judicial Discretion: An Empirical Test of Economic Models, "International Review of Law and Economics" 1996, Vol. 16, pp. 295-313.
} 
Rules help when making routine choices and making decisions but they deprive the action taker from freedom of conscious, premeditated and fully voluntary actions. They do not foresee and cover all possible contingencies and they are not always specific enough to provide unambiguous guidance which indicates what options must be taken and which must be avoided. Most often they are based on the prior evaluative power of other experts or skilled decision makers who prepare the rules to be followed. Therefore, rule compliance and followership do not provide fully personal, individual choices, for which full responsibility is taken.

This procedural reductionism ${ }^{17}$ inclines the decision makers to reduce all matters of judgment and responsibility to the following of some procedure or rule. Examples of this belief can be found in widespread attitudes, especially among the professionals, so that we are able to grasp good practice, devise good solutions, and make correct moral choices, by following rules and procedures.

It is the power of one's own judgment and discretion, to the extent that they are valid and accurate, which often marks the true professional decision maker ${ }^{18}$. The sense of discretion, the "power of free decision, individual judgment or choice within certain legal bounds' ${ }^{19}$ and the 'ability to make decisions which represent a responsible choice' ${ }^{20}$ presuppose the awareness of the subject of what is lawful, right, or wise in the matter of the discretion. As Hunt rightly remarks:

(...) professionalism cannot be reduced to the strict observance of procedures or
rules of accountability. It is certainly a mark of professionalism that behavior is
constrained and guided by procedures and rules of accountability, [but] it is quite
wrong to conclude that the more observant one is, the more p rofe s s i n a l
one necessarily is. It is also quite wrong to conclude that the more one constrains
professional activity with procedures and rules the be t ter (more effective,
safer, satisfying, happier or whatever) the practice, such as nursing, necessarily
is. Furthermore, it is wrong to think that whenever something goes wrong, appar-
ently because there is not a procedure that covers that eventuality, all that is
needed to put things right is another procedure or subprocedure or sub-subpro-
cedure. ${ }^{21}$

Following procedures and observing the rules are a good start in professional practice and in education. They provide a communicable vehicle offering help to the learning students and beginning practitioners in gaining knowledge of what is exemplary behaviour, an ideal or a pattern of good practice. Such knowledge is more easily accepted by students, since 'procedure is teachable, wisdom is gained by some through living their lives, including their professional lives, in an open and responsible spirit. This is what professional discretion is ultimately about. ${ }^{22}$

\footnotetext{
${ }^{17}$ G. Hunt, The Human Condition of the Professional: Discretion and Accountability, "Nursing Ethics" 1997, Vol. 4, No. 6, p. 519.

${ }^{18}$ Ibidem.

${ }^{19}$ Merriam-Webster Dictionary 2000.

${ }^{20}$ Ibidem.

${ }^{21}$ G. Hunt, op. cit., p. 521-522.

${ }^{22}$ Ibidem.
} 
But for responsible conduct and moral professional development mere knowledge transfer is not enough: active discussion, personal involvement, problem solving and hands-on experience of participative practice are necessary instead. ${ }^{23}$

\section{Discretion in engineering profession}

Within the discipline of engineering, in which speculative inquiry prevails, practice is the end - the applicability of the end results. Therefore, the principles derived from the research form a foundation of knowledge which is practical science. The decisions and abilities to apply the end results, be the new technologies, novel products, production techniques, invented constructions or just scientific principles in a particular situation, is the art of practice.

Speculative intellectual virtues perfect the intellect, but not the will or the habitual part of professional dispositions. An engineer may be well educated and of excellent knowledge about how to make efficient designs of civil constructions, mechanical machinery, how to behave in various situations and even learn what is the morally correct behaviour. Such knowledge is merely the perfection of the intellect. But the same engineer, if placed in such a challenging situation, may fail to stand up to the challenges. He could make the wrong use of the invention, or design, or behave immorally.

Examples involving decisions using some extent of discretion are most often yes/no decisions: to permit a building for public use, to issue/suspend a professional license, to issue a homologation certificate for an airplane, train, ship, car, ferry, traffic control system, etc. These complex and multistage decisions are usually reinforced by scores of specific standards, rules and conditions, all designed to make the final decision easier and right, but it is always some person who makes it in the end. Behind the multiple checks lists and cross checks there is always personal discretion and judgment that these machines or systems can safely and reliably operate within the specified fields of use with no detrimental effects to human health, life or welfare.

Discretion operates correctly whenever the decision maker uses truth as the principle upon which his decision or action is based. The usage of truth as a moral value rather than a scientific one has another advantage. The intent of the words and statements accurately reflect the dispositions of the mind of the speaker. Verity and truth telling, so often included as professional virtues in codes of professional engineering ethics, find a more comprehensive justification here. This enables the professional his or her personal moral development in the process of using discretion, conscientious judgment, prudence-related virtues, their habituation and deliberation.

\footnotetext{
${ }^{23}$ M. Davis, op. cit., p. 790.
} 


\section{Conclusion}

In the Aristotelian-Thomistic ethical system there is a fundamental difference between actus hominis (an act of a man) ${ }^{24}$ and actus humanus (a human act). ${ }^{25}$ While the first one denotes a man's act which does not involve the wholeness of his person, the other includes both human reason, (free) will, acting conscience and good habits - the components of the inner person's structure. ${ }^{26}$ Whenever a person actively involves these personal faculties in the act, it is called human and attains a moral value. Not all of the acts are moral acts, only those which are conscious, rational and wilfully committed.

In the expositions of this paper and the previous one ${ }^{27}$ it is clear that rules and regulations provide such a capacity for human acts to the extent that they allow for the involvement of the aforementioned personal faculties. As we have observed, this may be problematic and, when acts are repeated on a routine basis with shortcuts or without deliberation, they do not involve the whole human personality. Thus, they may not contain moral value or they may not be good acts. For example, a 'professional' person may commit deeply evil acts, even without being cognizant of them, and give reasons for it by stating 'I have only followed the prescripts of the law and rules of practice,' thereby suggesting that his own conscience and deliberation of the acts were not in operation while the acts had been committed. ${ }^{28}$

The review of the economic and professional literature suggests that the authors discern cases where rule-driven decision making should be made from those in which the decision makers should rely on their own discretion. In fact, the above analysis rather suggests that, in terms of the moral value of an action taken, there should be no difference between these two categories if the moral decision is to be taken by a professional person. Whether rules or the discretion are in use, the right decision is right no matter what helped more to make it. A good act is good no matter what helped the action taker to carry it out, whether good rules or well-made discretion followed by judgment - the good act is objectively good. What do make the difference in making a decision, or committing an act by a human person, are the components necessary for the correct decision and the good act, especially those discussed earlier in this paper. Whether the whole person participates in the act, only in part, or just passively and automatically follows the rules, this makes a fundamental difference on the moral value and the effects of the act. In the first case, it is truly moral and the effects are twofold: external (outside the person) and internal to the person. In the case of automated followership, only the external effect appears without (or with very limited) internal personal effect. When subsequent acts are

\footnotetext{
${ }^{24}$ Cf. T. Aquinas, Summa theologica, Ia IIae, q.18 a.2,3.

${ }^{25}$ Cf. ibidem, Ia IIae, q.6 seqq.; q.18 a.1,4,5; q. 21 a.1,3,4.

${ }^{26}$ Good intention, good end and other components of the structure of a human act were not discussed here for space limitations.

${ }^{27}$ P. Wajszczyk, op. cit.

${ }^{28}$ Similar effect can result when a person follows internal organizational rules, regulations or instructions without own conscientious discretion based on deliberation.
} 
morally good they contribute to the development of good habits, the person's permanent abilities to act morally well. In such a way, professional practice may be complemented by the moral development of an acting person. Future studies should investigate the applicability of the proposed Aristotelian-Thomistic framework in field research and find out the extent to which various professional people use it in their personal and organizational behaviours.

\section{References}

Angelis J., G. Parry, M. Macintyre, Discretion and Complexity in Customer Focused Environments, "European Management Journal" 2012, Vol. 30, pp. 466-472.

Aragón-Correa J.A., F. Matías-Reche, M.E. Senise-Barrio, Managerial discretion and corporate commitment to the natural environment, "Journal of Business Research" 2004, Vol. 57, pp. 964-975.

Arnaud S., D.M. Wasieleski, Corporate Humanistic Responsibility: Social Performance through Managerial Discretion of the HRM, "Journal of Business Ethics" 2014, Vol. 120, pp. 313-334.

Bowen T.R., D.M. Kreps, A. Skrzypacz, Rules with Discretion and Local Information, "The Quarterly Journal of Economics" 2013, pp. 1273-1320.

Cooter R.D., T. Ginsburg, Comparative Judicial Discretion: An Empirical Test of Economic Models, "International Review of Law and Economics" 1996, Vol. 16, pp. 295-313.

Davis M., A Plea for Judgment, "Science and Engineering Ethics" 2012, Vol. 18, pp. 789-808.

Einat T., Sentencing rationales, judicial discretion, and the practice of criminal fines in Israel, "Journal of Criminal Justice" 2008, Vol. 36, pp. 444-452, doi: 10.1016/j.jcrimjus.2008.07.007.

Hunt G., The Human Condition of the Professional: Discretion and Accountability, "Nursing Ethics" 1997, Vol. 4, No. 6, pp. 519-526.

Hutzschenreuter T., I. Kleindienst, (How) Does discretion change over time? A contribution toward a dynamic view of managerial discretion, "Scandinavian Journal of Management" 2013, Vol. 29, pp. 264-281.

Kunreuther H., M. Pauly, Rules Rather Than Discretion: Lessons from Hurricane Katrina, "Journal of Risk and Uncertainty" 2006, Vol. 33, pp. 101-116.

Melé D., Ethical Education in Accounting: Integrating Rules, Values and Virtues, "Journal of Business Ethics" 2005, Vol. 57, pp. 97-109.

Merriam-Webster Dictionary (2000).

Naveh E., Formality and discretion in successful R\&D projects, "Journal of Operations Management" 2007, Vol. 25, pp. 110-125.

Roychowdhury S., X. Martin, Understanding Discretion in Conservatism: An Alternative Viewpoint, "Journal of Accounting and Economics" 2013, Vol. 56, pp. 134-146.

Sahaym A., L.J. Treviño, H.K. Steensma, The influence of managerial discretion, innovation and uncertainty on export intensity: A real options perspective, "International Business Review" 2012, Vol. 21, pp. 1131-1147. 
St. T. Aquinas, Summa Theologica Literally Translated by Fathers of the English Dominican Province, Burns, Oates \& Washbourne, Benziger Brothers, New York, Cincinnati, Chicago 1922.

Wajszczyk P., Discretion in professional practice and in engineering ethics, "Annales. Etyka w Życiu Gospodarczym” 2015, Vol. 18, No. 4, pp. 129-136.

Waldron T.L., S.D. Graffin, J.F. Porac, J.B. Wade, Third-party Endorsements of CEO Quality, Managerial Discretion, and Stakeholder Reactions, "Journal of Business Research" 2013, Vol. 66, pp. 2592-2599.

Yan Y., Ch.Ch. Yan, S. Mak, An Exploration of Managerial Discretion and Its Impact on Firm Performance: Task Autonomy, Contractual Control, and Compensation, "International Business Review” 2010, Vol. 19, pp. 521-530. 